Research article

\title{
Landfill leachate treatment by sequential membrane bioreactor and electro-oxidation processes
}

\author{
Mehdi Zolfaghari a , Karama Jardak ${ }^{\text {a }}$, Patrick Drogui ${ }^{\text {a, * }}$, Satinder Kaur Brar ${ }^{\text {a }}$, \\ Gerardo Buelna ${ }^{b}$, Rino Dubé ${ }^{b}$ \\ a Institut National de la Recherche Scientifique- Eau, Terre et Environnement (INRS-ETE), Université du Québec, 490 rue de la Couronne, Québec, QC, G1K \\ 9A9, Canada \\ ${ }^{\mathrm{b}}$ Centre de Recherche Industrielle du Québec (CRIQ), 333 rue Franquet, Québec, QC, G1P 4C7, Canada
}

\section{A R T I C L E I N F O}

\section{Article history:}

Received 12 July 2016

Received in revised form

4 October 2016

Accepted 5 October 2016

Available online $\mathrm{xxx}$

\section{Keywords:}

Landfill leachate

Membrane bioreactor

Electro-oxidation process

Energy consumption

Removal efficiency

Di 2-ethyl hexyl phthalate

\begin{abstract}
A B S T R A C T
Combination of high performance membrane bioreactor (MBR) equipped with ultrafiltration and electrooxidation process (EOP) by boron-doped diamond electrode (BDD) was used to effectively treat highly contaminated old landfill leachate. MBR and EOP were optimized for raw and pretreated landfill leachate. Seasonal changes dramatically affected the both processes' performance, as the landfill leachate was $3 / 4$ more concentrated in winter. For MBR, organic load rate of $1.2 \mathrm{gCOD} / \mathrm{L} /$ day and sludge retention time of 80 days was considered as the optimum operating condition in which COD, TOC, $\mathrm{NH}_{4}^{+}$and phosphorous removal efficiencies reached the average of $63,35,98$ and $52 \%$, respectively. The best performance of EOP was in current intensity of $3 \mathrm{~A}$ with treatment of time of $120 \mathrm{~min}$. Effluent of electro-oxidation was more toxic due to the presence of radicals and organochlorinated compounds. These compounds were removed by stripping or assimilation of sludge if EOP was used as a pretreatment method. Furthermore, the energy consumption of EOP was decreased from 22 to $16 \mathrm{KWh} / \mathrm{m}^{3}$ for biologically treated and raw landfill leachate, respectively.
\end{abstract}

Crown Copyright $\odot 2016$ Published by Elsevier Ltd. All rights reserved.

\section{Introduction}

Among prevalent high quantity wastewater, landfill leachate (LFL) is undoubtedly one of the most challenging wastewaters in terms of treatment (Gotvajn et al., 2009; Urtiaga et al., 2009; Zhou et al., 2016), due to several reasons. Firstly, flow rate of LFL largely varied by season and age of landfill. Secondly, its characteristic widely depended on years of operation, amount of precipitation, and type of landfilling. Finally, it has high concentration of ammonia and toxicity, low (biochemical oxygen demand/chemical oxygen demand (BOD/COD) ratio, and presence of heavy metals and emerging contaminants (Kjeldsen et al., 2002). As LFL gets older, the more complex dissolved organic matter (DOM) are produced out of simple ones, dramatically decreasing the COD removal efficiency of biological treatment; hence, physio-chemical processes installation seems to be inevitable for proper elimination of recalcitrant DOM (Aloui et al., 2009; Bashir et al., 2013; Gotvajn et al., 2009). Intense brown coloration of old landfill leachate

\footnotetext{
* Corresponding author.

E-mail address: patrick.drogui@ete.inrs.ca (P. Drogui).
}

indicates the presence of these DOM with high molecular weight, known as humic substances (HS), which act as the best media for adsorption of metal and emerging contaminants (Panizza and Martinez-Huitle, 2013). Furthermore, LFL has the highest detection rate and concentration of variety of emerging contaminants among wastewaters (Oturan et al., 2015).

Conventional biological processes are expectedly inefficient for treatment of LFL because of low BOD, and phosphorous concentration, while high concentration of ammonia and emerging contaminant. Membrane bioreactors (MBR), therefore, are widely used in LFL treatment plant, due to high performance in ammonia removal by biological nitrification or air stripping (Ahmed and Lan, 2012; Gotvajn et al., 2009), metal and emerging contaminant by sludge adsorption, and finally turbidity and suspended solid by the membrane (Ahmed and Lan, 2012). The concentrated effluent of MBR contains refractory compounds, mainly HS, with low amount of ammonia and metal which is ideal for advanced oxidation process (AOP) (Schwarzenbeck et al., 2004), especially electrooxidation process (EOP) (Urtiaga et al., 2009; Zhou et al., 2016). The main objective of EOP utilization is either removal or transformation of humic substances into biodegradable organic matter (Panizza and Martinez-Huitle, 2013), or maximum elimination of 


\author{
List of symbols \\ AOP Advanced Oxidation Processes \\ BDD Boron-doped diamond \\ BOD Biochemical Oxygen Demand \\ CCD Central Composite Design \\ COD Chemical Oxygen Demand \\ DEHP Di 2-ethyl hexyl phthalate \\ DOM Dissolved Organic Matter \\ EC Electrical Conductivity \\ EOP Electro-oxidation Process \\ FD Factorial Design \\ F/M ratio Food/Microorganism Ratio
}

$\begin{array}{ll}\text { HA } & \text { Humic Acid } \\ \text { HRT } & \text { Hydraulic Retention Time } \\ \text { HS } & \text { Humic Substances } \\ \text { LFL } & \text { Landfill Leachate } \\ \text { MBR } & \text { Membrane Bioreactor } \\ \text { MLSS } & \text { Mixed Liquor Suspended Solid } \\ \text { MLVSS } & \text { Mixed Liquor Volatile Suspended Solid } \\ \text { SRT } & \text { Sludge Retention Time } \\ \text { TA } & \text { Total Alkalinity } \\ \text { TCU } & \text { True Color Unit } \\ \text { TS } & \text { Total Solid } \\ \text { VS } & \text { Volatile Solid }\end{array}$

COD when it is used as a post treatment. COD in EOP was mainly removed by direct oxidation (oxidation on the surface of electrode or by hydroxyl radical), while ammonia was removed by means of indirect oxidation (reaction with chlorine oxidant) (reaction in supplementary files: appendix A) (Bashir et al., 2009; Chu et al., 2015; Deng and Englehardt, 2007; Panizza and Martinez-Huitle, 2013).

Sludge management of LFL treatment plant was also a concern, due to high concentration of pollutants; hence, low quantity or zero production of sludge will be favorable that could be achieved by simultaneous utilization of MBR and EOP (Zhou et al., 2016). Both processes are well-known in the formation of low quantity of solid residue and removal of emerging contaminants (Fernandes et al., 2012).

Till this date, all the studies have investigated EOP as posttreatment of biological treated landfill leachate (Aloui et al., 2009; Bashir et al., 2013; Chu et al., 2015; Fernandes et al., 2012; Urtiaga et al., 2009), though production of organochlorine compounds and remaining radicals are the main problems. In this study, combination of MBR and EOP was used in the optimal sequence to effectively treat old landfill leachate. Firstly in MBR, sludge was developed and optimized according to various operating conditions and seasonal changes. Secondly, factorial and central composite design models were used to estimate the optimal conditions for oxidation performance. Finally, the optimized sequence of two processes was determined based on best removal efficiency, lowest energy consumption and toxicity. The fate of Di 2ethyl hexyl phthalate (DEHP) was also investigated as the model of hydrophobic emerging contaminants in landfill leachate.

\section{Material and methods}

\subsection{Landfill leachate sampling}

Municipal landfill leachate employed in this study, was collected from Frampton's landfill, (Québec, Canada) with capacity of 180 tons/day and annual average production of $100 \mathrm{~m}^{3} /$ day landfill leachate. The landfill was located around $60 \mathrm{~km}$ to south east of Quebec City, received waste mainly from Levis household agglomeration, Québec, Canada. Samples were monthly taken from $2750 \mathrm{~m}^{3}$ storage tank and before aeration pretreatment. All samples were instantly stored at $4{ }^{\circ} \mathrm{C}$ before applying to MBR or EOP. The flow rate and characteristic of LFL varied from season to season, despite the fact that the high precipitation was evenly distributed throughout the year. In spring (April and May), precipitation and melting of snow results in higher production of diluted landfill leachate. The precipitation in winter (between December to March) is in the form of snow. Furthermore, freezing temperature (Fig. 1-S), dramatically decreases LFL production. As a consequence, the characteristic of raw landfill leachate fluctuated from being heavily loaded in winter to highly diluted throughout spring and summer. It is worth mentioning that Frampton landfill leachate treatment processes contains aeration tank, as pretreatment, followed by biological aerated lagoon, and peat adsorption for the post treatment.

\subsection{Experimental pilots}

Membrane bioreactor used in this study comprised $5 \mathrm{~L}$ aeration tank, a submerged hollow fiber ultrafiltration (ZW-1, Zenon environmental Inc.) with nominal pore size of $0.04 \mu \mathrm{m}$ and total filtration surface area of $0.047 \mathrm{~m}^{2}$. Feed and filtration peristaltic pumps were controlled for cycle of $110 \mathrm{~s}$ of filtration and $10 \mathrm{~s}$ of backwash by four times flow rate of filtration. The automatization and membrane wash was fully described in previous study (Zolfaghari et al., 2016).

Electro-oxidation lab scale cell comprised 1-L Plexiglas storage tank, 1 -L reaction tank (dimension of $10 \times 5 \times 12 \mathrm{~cm}$ ) equipped with an anode and a cathode with an inter-electrode gap of $2 \mathrm{~cm}$. The anode had a solid surface area of $65 \mathrm{~cm}^{2}$, thickness of $0.1 \mathrm{~cm}$ and the void surface area of $45 \mathrm{~cm}^{2}$. The rectangular anode electrode was made of niobium coated with boron doped diamond $(\mathrm{Nb} /$ BDD), while the cathode was made of titanium with same physical characteristic of anode. The current was provided by a DC power supplier xantrex XFR 40-70 VA (Aca Tmetrex, Mississauga, Ontario, Canada). A peristaltic pump with flow rate of $170 \mathrm{~mL} / \mathrm{min}$, was used for recirculation of liquid between storage and reaction tank. A magnet stirrer was also used in reaction tank to homogenize the liquid. The schematic of both reactors are shown in supplementary files (Fig. 2-S).

\section{3. $M B R$ startup}

The MBR pilot was initially inoculated by activated sludge collected from east municipal wastewater treatment plant of Quebec City, Quebec, Canada. Development of proper microorganisms was performed under continuous mode by setting the hydraulic retention time (HRT) at $48 \mathrm{~h}$, and sludge retention time (SRT) of 200 days by raw LFL. During 28 days of startup stage, sludge concentration (represented by volatile solids (VS) concentration) was increased from $2.5 \mathrm{~g} / \mathrm{L}$ to $7.1 \mathrm{~g} / \mathrm{L}$. Later on, HRT was gradually decreased to $18 \mathrm{~h}$, to develop nitrification and assess the performance of MBR under different operating conditions. During all sets of experiments, dissolved oxygen and temperature was kept 
higher than $7 \pm 0.8 \mathrm{mg} \mathrm{O} \mathrm{O}_{2} / \mathrm{L}$ and around $17.5 \pm 1{ }^{\circ} \mathrm{C}$, respectively.

\subsection{EOP experimental design}

For the modeling and optimization of process, central composite design (CCD) was applied; while, factorial design (FD) was used for understanding the statistical significance of variable parameters include: current intensity $\left(\mathrm{X}_{1}\right)$, treatment time $\left(\mathrm{X}_{2}\right)$ and seasonal changes $\left(\mathrm{X}_{3}\right)$. As ammonia and metal removal was almost independent of operating condition, COD and total organic carbon (TOC) removal efficiency was considered as the responses of the models. Eight sets of experiments were needed for FD in which each factor was fixed in its extreme limit. In CCD model, on the other hand, 18 additional sets of experiments were required in which fixed experiment was run at center of domain, while the other four were axial assays for each categorical factor (sequence of experiments in supplementary files: Table $1-S$ ).

In factorial design, the effect of each factor and their interaction was estimated according to the following model (Eq. (1)):

$Y=b_{0}+b_{1} X_{1}+b_{2} X_{2}+b_{3} X_{3}+b_{12} X_{12}+b_{13} X_{13}+b_{23} X_{23}$

in which $Y$ is the experimental response, $b_{0}$ is the average value of response of all eight experiment, $X_{i}$ is the variables, $b_{i}$ stands for effect of each factor and finally $b_{i j}$ represents interaction effect of variable $\mathrm{i}$ and $\mathrm{j}$ on response. Experimental coefficient (b) was measured using half difference between arithmetic averages of the responses for extreme values of variable. For optimization of each factor, CCD model was performed by means of eighteen extra experiments and estimated the result by second order model (Eq. (2)).

$Y=b_{0}+\sum b_{i} X_{i}+\sum b_{i i} X_{i}^{2}+\sum b_{i j} X_{i} X_{j}+e_{i}$

in which $b_{i}, b_{i i}$ and $b_{i j}$ are the liner, quadratic and interactive effects of specified variable and $e_{i}$ represents the residual term. Design expert software (design expert 7, State-Ease Inc., Minneapolis, USA) was used to calculate these coefficients of polynomial model. The experimental condition and values of responses was fully described in supplementary files (Table 1-S). Due to the high concentration of mineral in raw and treated landfill leachate, supporting electrolyte was not necessary during electrolysis. The mass transfer coefficient was kept at highest point by increasing the recirculating pump flow rate at its maximum $(170 \mathrm{~mL} / \mathrm{min})$.

\subsection{Sampling and analysis}

For monitoring MBR, the inlet and outlet samples were taken twice per week. For EOP, samples were taken at the end of each experiment. For both experiments, one of the $50 \mathrm{~mL}$ sample was acidified, and both neutral and acidified samples kept at $4{ }^{\circ} \mathrm{C}$, prior to the analysis. Slurry samples were directly extracted from MBR in the same time sequence for measuring total and volatile solids (TS, VS). The analysis method of COD, $\mathrm{BOD}_{5}$, color, TOC, $\mathrm{N}_{\text {tot }}$, Ammonia, nitrate, nitrite and ortho-phosphate TS, VS, mixed liquor suspended solid (MLSS), mixed liquor volatile suspended solid (MLVSS), total alkalinity (TA) and Daphnia and Vibrio fischeri bioluminescence toxicity were adopted from previous study by Zolfaghari et al. (2016, 2015).

Liquid-liquid extraction with dichloromethane (DCM) was used for the extraction and GC/MS with the $N$-pentadecane as an internal standard for the analysis of DEHP (recovery of 81\%). As the binding between DEHP and HS was reversible in presence of DCM, adsorbed DEHP could be easily extracted by L/L extraction (Akkanen et al., 2001). The analysis of DEHP by GC/MS was fully described in previous studies (Zolfaghari et al., 2016).

\section{Results}

\subsection{MBR optimization for treatment of raw $L F L$}

After development of desired concentration of activated sludge, four stages of assimilation were performed according to the mentioned operating condition in Table 1. By gradual increase of HRT, organic load rate (OLR) was increased, resulting in extra growth of sludge. For controlling fouling rate, therefore, SRT should slowly decrease. By decrease of HRT in the fourth stage, F/M ratio suddenly increased higher than normal range, making the operation unstable. Color, COD and TOC removal was selected to determine the performance of MBR in different stages. According to Fig. 1, the best COD, TOC and color removal was at HRT of $32 \mathrm{~h}$, and SRT of 160 days with value of $65.8,33.2$, and $20.9 \%$, respectively. Although the nitrification started at HRT of $18 \mathrm{~h}$ (at day 57), the performance of MBR was dramatically decreased due to the high organic load rate (2.1 g COD/L/day). By keeping low SRT during assimilation period, volatile solids concentration was gradually increased to $9 \mathrm{~g} / \mathrm{L}$.

The optimization period was run upon completion of assimilation period with the following operating conditions: HRT $=32 \mathrm{~h}$, $\mathrm{SRT}=80$ day, TS and VS concentration of 16.48 and $8.94 \mathrm{~g} / \mathrm{L}$, respectively. SRT was decreased from 160 days to 80 days for normalization of TS and VS concentration, and regulating of the membrane fouling. Start-up of the reactor was done in early June, when LFL was diluted by high precipitation. By changing the season, the precipitation was mainly in the form of snow, and the liquid in landfill was frozen, that result in significant change in LFL flow rate and characterization. Hence, the optimization period was divided into two different stages. In Table 2, the characteristic of LFL and the performance of MBR for all parameters were described. The EC was rising from 6.5 in summer into the average of $11.8 \mathrm{~m} /$ $\mathrm{cm}^{2}$ in winter, indicated $80 \%$ increase of dilution in summer

Table 1

Operating conditions during assimilation period of MBR (average \pm standard deviation).

\begin{tabular}{|c|c|c|c|c|}
\hline \multirow[t]{2}{*}{ Parameter (unit) } & \multicolumn{4}{|l|}{ Stage } \\
\hline & 1 & 2 & 3 & 4 \\
\hline Operation period (day) & 20 & 14 & 14 & 14 \\
\hline HRT (h) & 44 & 32 & 24 & 18 \\
\hline SRT (day) & 200 & 160 & 50 & 35 \\
\hline $\mathrm{TS}(\mathrm{g} / \mathrm{L})$ & $9.131 \pm 2.131$ & $11.255 \pm 1.019$ & $15.815 \pm 2.314$ & $14.423 \pm 2.212$ \\
\hline $\operatorname{VS}(\mathrm{g} / \mathrm{L})$ & $6.432 \pm 1.412$ & $6.996 \pm 0.871$ & $8.847 \pm 1.012$ & $7.58 \pm 1.134$ \\
\hline Turbidity (NTU) & $309 \pm 52$ & $304 \pm 48$ & $422 \pm 75$ & $339 \pm 61$ \\
\hline $\mathrm{EC}(\mathrm{ms} / \mathrm{cm})$ & $6.47 \pm 0.61$ & $6.54 \pm 0.74$ & $6.47 \pm 0.39$ & $6.85 \pm 0.12$ \\
\hline OLR (g COD/L/day) & $0.953 \pm 0.271$ & $1.3 \pm 0.282$ & $1.562 \pm 0.312$ & $2.104 \pm 0.121$ \\
\hline F/M ratio (kg COD/kg VS/day) & $0.203 \pm 0.081$ & $0.174 \pm 0.073$ & $0.17 \pm 0.061$ & $0.286 \pm 0.049$ \\
\hline
\end{tabular}




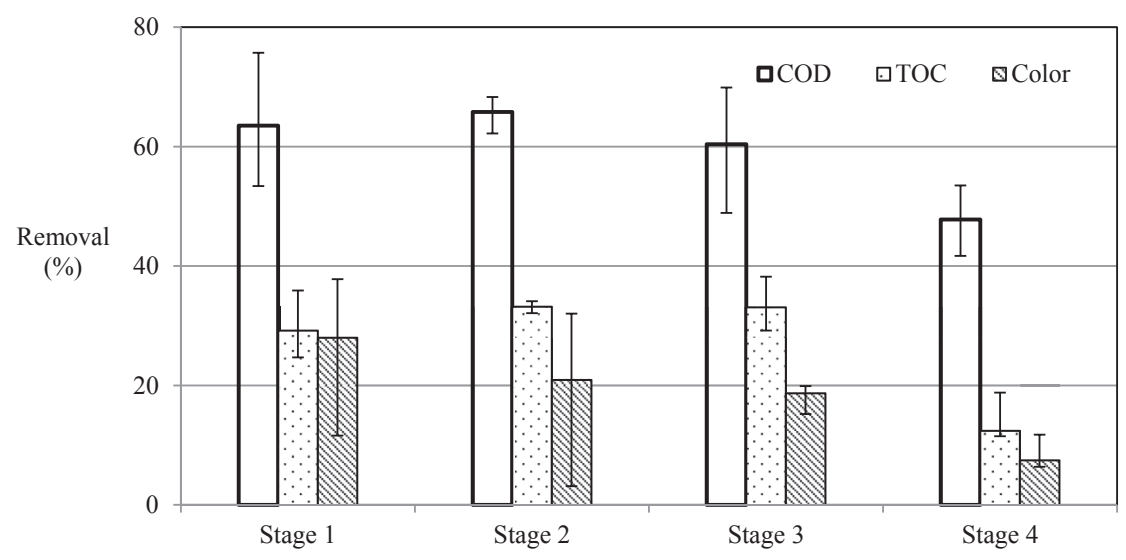

Fig. 1. Performance of MBR during the assimilation period for COD, TOC and Color removal (operating condition of each stages mentioned in Table 1).

(between June to August). Average COD and TOC concentration was around 1550 and $323 \mathrm{mg} / \mathrm{L}$, respectively that 26\% less concentrated than winter. In summer, the average concentration of $\mathrm{BOD}_{5}$ was decreased from 242 to $127 \mathrm{mg} / \mathrm{L}$, due to the high activity of heterotrophic bacteria in utilization of biodegradable carbon. Furthermore, high average temperature in summer might result in stripping of ammonia; decrease its concentration to $288 \mathrm{mg} / \mathrm{L}$. Likewise, the average TA concentration was $2515 \mathrm{mg} \mathrm{CaCO}_{3} / \mathrm{L}$, which was $51 \%$ lower than the concentration in winter. High bacterial activity inside landfill, might also convert organic phosphorous into orthophosphate; yet, the concentration of phosphorous never rose more than $7 \mathrm{mg} \mathrm{P} / \mathrm{L}$, due to its precipitation by metal, especially by aluminum cations.

According to Table 2, performance of MBR was not affected for ammonia and TA removal, as the temperature of aeration basin remained constant. Due to the high concentration of sludge, the entire inlet BOD was removed in MBR. Toxicity is tightly connected to ammonia, metal and emerging contaminants in liquid phase. As the performance of MBR remained same for $\mathrm{NH}_{4}^{+}$, DEHP and metal removal, the toxicity of outlet remained same, in spite of seasonal changes. Removal of phosphorous on the other hand, enhanced in winter, because of higher assimilation rate by microorganisms ( $6 \mathrm{mg} \mathrm{P} / \mathrm{g}$ of sludge). COD, TOC and color were tightly connected with recalcitrant DOM; so, their removals were significantly decreased in winter. Finally, turbidity of outlet remained below 10 NTU, as the ultrafiltration blocked the passage of suspended solid and colloids.

\subsection{EOP optimization for treatment of MBR effluent}

The performance of EOP is specifically depended on the different factors, such as the type of anodes, treatment time, current density, electrolyte addition, recycling flow rate and $\mathrm{pH}$ (Fernandes et al., 2012). The recycling flow rate was kept as high as possible to reach the maximum hydrodynamic performance (Urtiaga et al., 2009).

High EC in both raw LFL and effluent of MBR (Tables 1 and 2), eliminated the addition of extra electrolyte for electro-oxidation process. Furthermore, there is a census on using boron-doped diamond on the base of niobium (Nb/BDD) anode for landfill leachate treatment due to its acceptable corrosive resistance, low adsorption properties and high catalytic activity (Anglada et al., 2011; Bashir et al., 2013; Fernandes et al., 2012). The comparison of electrode by Panizza and Martinez-Huitle (2013) showed that COD and TOC removal efficiency was completed by BDD utilization instead of other electrodes, such as lead and rubidium oxides. BDD also showed better current efficiency because of greater production of $\mathrm{OH}^{\bullet}$ radical, and very faint $\mathrm{OH}^{\bullet}$ adsorption (Panizza and Martinez-Huitle, 2013; Zhou et al., 2016). pH also, plays an important role in oxidation of ammonium, as it determines the distribution of highly reactive $\mathrm{HClO}$ or weak oxidant $\mathrm{ClO}^{-}$ions (Aloui et al., 2009). All the reaction for organic matter and ammonia are mentioned in appendix A. Initial experiments were required to know the range of current intensity and treatment time for optimization of EOP. Current intensity and treatment time was

Table 2

Seasonal performance of MBR in optimum operating conditions (average \pm standard deviation).

\begin{tabular}{|c|c|c|c|c|c|c|}
\hline \multirow[t]{2}{*}{ Parameter (unit) } & \multicolumn{3}{|l|}{ Summer } & \multicolumn{3}{|l|}{ Winter } \\
\hline & Inlet & Outlet & Removal (\%) & Inlet & Outlet & Removal (\%) \\
\hline $\mathrm{COD}\left(\mathrm{mgO}_{2} / \mathrm{L}\right)$ & $1550 \pm 239$ & $568 \pm 121$ & $63.4 \pm 12.2$ & $2122 \pm 412$ & $993 \pm 98$ & $53.2 \pm 2.7$ \\
\hline $\mathrm{TOC}(\mathrm{mgC} / \mathrm{L})$ & $323 \pm 61$ & $209 \pm 15$ & $35.3 \pm 15.4$ & $434 \pm 87$ & $333 \pm 25$ & $23.3 \pm 4.6$ \\
\hline $\mathrm{BOD}_{5}\left(\mathrm{mgO}_{2} / \mathrm{L}\right)$ & 127 & 5 & 96.5 & 242 & 9.7 & 96.0 \\
\hline $\mathrm{NH}_{4}(\mathrm{mgN} / \mathrm{L})$ & $288 \pm 112$ & $5 \pm 4.5$ & $98.2 \pm 1.7$ & $667 \pm 85$ & $5.1 \pm 3.9$ & $99.2 \pm 0.7$ \\
\hline $\mathrm{NO}_{3}(\mathrm{mgN} / \mathrm{L})$ & $0.5 \pm 0.6$ & $189 \pm 102$ & & $1.1 \pm 0.5$ & $625 \pm 82$ & \\
\hline $\mathrm{N}_{\text {tot }}(\mathrm{mgN} / \mathrm{L})$ & $299 \pm 115$ & $209 \pm 122$ & $27.7 \pm 2.1$ & $700 \pm 89$ & $630 \pm 82$ & $9.7 \pm 1.5$ \\
\hline $\mathrm{PO}_{4}(\mathrm{mgP} / \mathrm{L})$ & $4.3 \pm 1.5$ & $2.1 \pm 2.2$ & $52.5 \pm 32.6$ & $2.7 \pm 0.9$ & $0.6 \pm 0.5$ & $77.8 \pm 8.4$ \\
\hline $\mathrm{P}_{\text {tot }}(\mathrm{mgP} / \mathrm{L})$ & $6.4 \pm 1.1$ & $2.1 \pm 1.9$ & $67.2 \pm 20.5$ & $5.2 \pm 0.9$ & $0.7 \pm 0.9$ & $86.5 \pm 12.7$ \\
\hline $\mathrm{TA}\left(\mathrm{mgCaCO}_{3} / \mathrm{L}\right)$ & $2515 \pm 549$ & $732 \pm 213$ & $70.9 \pm 9.8$ & $5197 \pm 1019$ & $684 \pm 128$ & $86.8 \pm 5.0$ \\
\hline Toxicity-Daphnia (Uta) & 7.1 & 1.1 & 84.5 & 15 & 1.2 & 92 \\
\hline Toxicity-Vibrio fischeri (Uta) & 26 & 2.4 & 90.8 & 53 & 2.8 & 94.7 \\
\hline Color (TCU) & $1230 \pm 344$ & $877 \pm 58$ & $28.7 \pm 11.2$ & $1621 \pm 284$ & $1580 \pm 273$ & $2.5 \pm 0.5$ \\
\hline $\mathrm{EC}(\mathrm{ms} / \mathrm{cm})$ & $6.5 \pm 0.7$ & $5.3 \pm 0.5$ & & $11.8 \pm 1.1$ & $10.4 \pm 1.4$ & \\
\hline Turbidity (NTU) & 304 & ND & 100.0 & 652 & ND & 100 \\
\hline $\mathrm{DEHP}(\mu \mathrm{g} / \mathrm{L})$ & $43.2 \pm 12$ & $17.7 \pm 22$ & $59.0 \pm 24.3$ & $57.1 \pm 9$ & $19.2 \pm 19$ & $66.4 \pm 28.8$ \\
\hline
\end{tabular}


gradually increased till the COD concentration in effluent was under $160 \mathrm{mg} / \mathrm{L}$, which satisfied standard regulation. As shown in Table 3, the mentioned removal efficiency was satisfactory for the current intensity of above $2 \mathrm{~A}$, treatment time of $120 \mathrm{~min}$, cathode and anode type of $\mathrm{Ti}$ and $\mathrm{Nb} / \mathrm{BDD}$, respectively. As Fernandes et al. (2015) stated constant COD rate with current density higher than $40 \mathrm{~mA} / \mathrm{cm}^{2}$, current intensity of $3 \mathrm{~A}$ (current density of $46 \mathrm{~mA} / \mathrm{cm}^{2}$ ) was selected as the upper range of our test. For understanding the effect of each factor on EOP, FD model was run for eight sets of experiment and the following mathematical models of COD and TOC removal efficiencies was gained by design expert software (Eqs. (3) and (4)),

$$
\begin{aligned}
\operatorname{COD} R E(\%)= & 49.34+2.99 \mathrm{X}_{1}+17.21 \mathrm{X}_{2}+5.09 \mathrm{X}_{3} \\
& +7.61 \mathrm{X}_{23} \mathrm{R}^{2} \\
= & 0.98
\end{aligned}
$$

$$
\begin{aligned}
\operatorname{TOC} R E(\%)= & 37.04+4.49 \mathrm{X}_{1}+9.29 \mathrm{X}_{2}+11.21 \mathrm{X}_{3} \\
& +3.54 \mathrm{X}_{23} \mathrm{R}^{2} \\
= & 0.92
\end{aligned}
$$

As the correlation coefficient was exceeded 0.8 , those models were acceptably predicted experimental data. Influence of each factors and their interaction were fully described by Pareto chart in supplementary files (Fig. 3-S). In order to determine the exact contribution of each factor, the following equation was used:

$P I=\left(\frac{b_{i}}{\sum b_{i}}\right) \times 100$

According to the results in Fig. 2, treatment time largely affected the COD removal efficiency, while seasonal change was the main variable contributing to TOC removal. The effect of current intensity on the other hand, was not significant in performance of EOP.

CCD model was used to optimize the EOP fosr both responses. By performing the experiments, the following equations were estimated by design expert software.

$$
\begin{aligned}
\operatorname{COD} R E(\%)= & 68.17+4.53 \mathrm{X}_{1}+15.21 \mathrm{X}_{2}+14.51 \mathrm{X}_{3}+0.66 \mathrm{X}_{12} \\
& +2.23 \mathrm{X}_{13}+6.08 \mathrm{X}_{23}-4.69 \mathrm{X}_{11} \\
& +7.91 \mathrm{X}_{22} \mathrm{R}^{2} \\
= & 0.83
\end{aligned}
$$

$$
\begin{aligned}
\text { TOC RE }(\%)= & 35.52+4.97 \mathrm{X}_{1}+9.48 \mathrm{X}_{2}+10.82 \mathrm{X}_{3}+3.54 \mathrm{X}_{12} \\
& +2.44 \mathrm{X}_{13}+2.1 \mathrm{X}_{23} \mathrm{R}^{2} \\
= & 0.98
\end{aligned}
$$

\section{Table 3}

Effect of current intensity and treatment time on COD removal efficiency (recirculation rate $=170 \mathrm{~mL} / \mathrm{min}$, temperature $21 \pm 1{ }^{\circ} \mathrm{C}, \mathrm{pH}$ initial $=8$, distance between electrode $=2 \mathrm{~cm}$, potential difference of $9.8 \pm 2 \mathrm{~V}$, type of electrodes Ti/BDD, volume of landfill leachate $=1 \mathrm{~L}$ ) (measured concentration \pm error of analysis).

\begin{tabular}{llll}
\hline Current intensity (A) & \multicolumn{4}{l}{ COD concentration $(\mathrm{mg} / \mathrm{L})$} \\
\cline { 2 - 4 } & initial & @ $1 \mathrm{~h}$ & @ 2 h \\
\hline 0.2 & $652 \pm 36$ & $585 \pm 2$ & $487 \pm 12$ \\
1 & $652 \pm 36$ & $352 \pm 2$ & $246 \pm 4$ \\
2 & $652 \pm 36$ & $297 \pm 8$ & $106 \pm 14$ \\
\hline
\end{tabular}

In order to evaluate the significance of the models, as well as good regression fitting of the obtained models, an ANOVA test could be carried out (fisher table is bring out in: Table 2-S). F value was calculated for each model based on $95 \%$ of confidential level. Since both calculated F-value for COD and TOC removal (11.06 and 175.83, respectively) was superior to Fc value, both models were significantly predictive. Furthermore, by comparing $\operatorname{Pr}>\mathrm{F}(0.01$ and $0.05 \%$ for COD and TOC removal) with $\alpha=0.05$, the credibility of model was proved. Finally, the fittness of COD and TOC removal models was significant, as both of the determination coefficients were higher than 0.8 . Models were acceptable and good correlation between predicted and actual values was expected (Supplementary files: Fig. 4-S). Based on following models, for maximizing TOC and COD removal efficiencies, the following condition was required: Electrode type of Ti/BDD, current intensity of $3 \mathrm{~A}$, current density of $46 \mathrm{~mA} / \mathrm{cm}^{2}$, treatment time of $120 \mathrm{~min}$ and effluent of MBR in summer season. The optimum prediction of TOC and COD removal efficiency was proved by running three experiments on the optimum conditions (supplementary file: Fig. 5-S).

\subsection{EOP as a post-treatment}

The optimum performance of electro-oxidation process for both seasons is illustrated in Table 4. Influent of EOP was mainly contained non-biodegradable HS and nitrate. As the concentration of DOM increased in winter, the performance of EOP was considerably decreased, especially for TOC. By comparing color and COD removal, it could be deduced that HS which give color to LFL, were rapidly degraded; yet, DOM with smaller molecular weight required more time for complete mineralization. Strangely, ammonia concentration was increased after EOP, especially in summer season, because of nitrate reduction on the surface of the cathode. Presence of hydroxyl radical in bulk solution resulted in high DEHP removal efficiency; yet, high concentration of organic matter in winter acted as a radical scavenger that cause insufficient degradation of emerging contaminants. The main problem associated with EOP was considerable increase in toxicity. $\mathrm{LC}_{50}$ decreased from 84 to only $13 \% \mathrm{v} / \mathrm{v}$ of LFL. Rapid increase in toxicity of effluent was mainly associated with presence of ammonia, residual concentration of radical and organochlorinated compounds that produced by reaction of organic matter and chlorine radical (Anglada et al., 2011).

\subsection{EOP as a pretreatment of $M B R$}

Residual carcinogenic, volatile organochlorine compounds and radicals might be stripped by intense aeration in aerobic treatment or adsorbed and assimilated by sludge. Besides, Chu et al. (2015) claimed that electro-oxidation significantly enhanced the biodegradability of LFL. It has been reported that BOD/COD ratio was greatly increased from 0.04 to 0.22 after 2 h (Chu et al., 2015). Consequently, EOP as a pretreatment of MBR could be an interesting option. As the suspended solid of LFL was deposited on the surface of electrodes and decreased the performance of chemical reaction, raw landfill leachate was filtered by microfiltration before introduction into electro-oxidation reactor. For understanding of the mechanism of electrochemical reaction, kinetic experiment of both raw and treated landfill leachate was investigated. Optimum condition of electro-oxidation was used for both effluent and raw landfill leachate. Based on literature (Bashir et al., 2013; Urtiaga et al., 2009), COD removal by electro-oxidation could be precisely fitted with the pseudo first order kinetics with $\mathrm{R}^{2}$ of $99 \%$ (Table 5).

Color removal rate was 3.5 times faster than TOC removal for both effluent and raw landfill leachate. As color mostly consists of large humic and fulvic acid molecule, high molecular weight DOM 


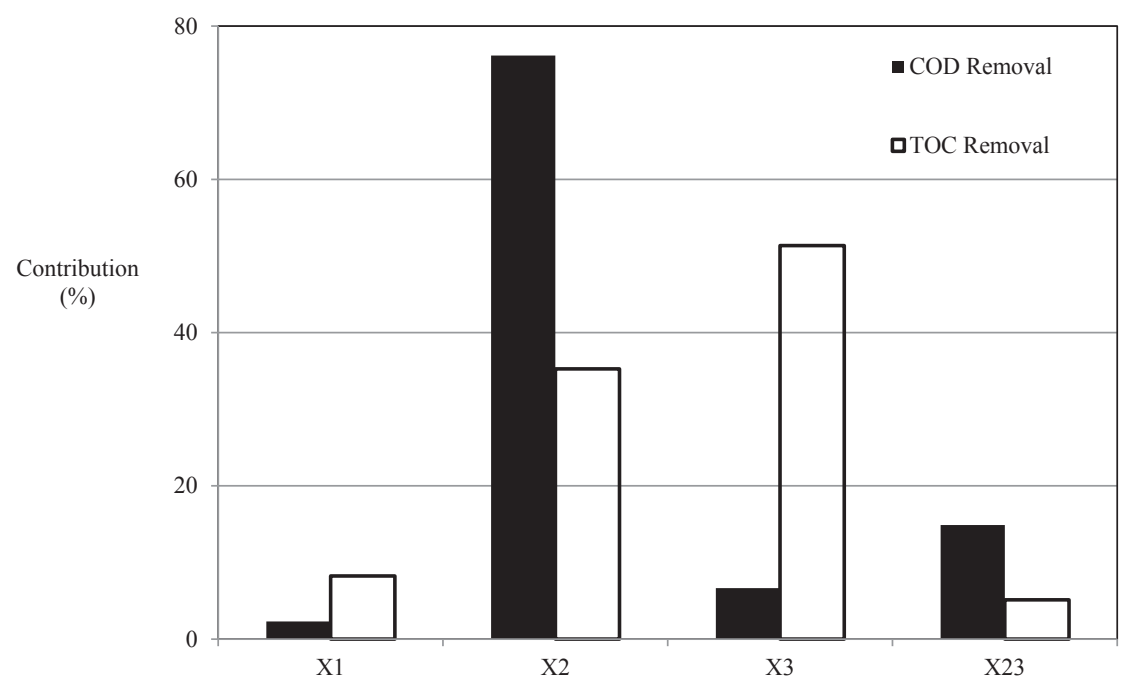

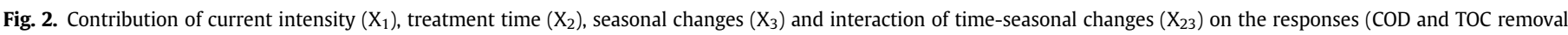
efficiency) in electro-oxidation process.

Table 4

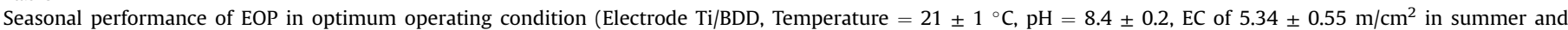
$9.97 \pm 0.81 \mathrm{~m} / \mathrm{cm}^{2}$ in winter, current intensity of $3 \mathrm{~A}$, voltage of $13.2 \mathrm{~V}$, reaction time of $120 \mathrm{~min}$ ).

\begin{tabular}{|c|c|c|c|c|c|c|}
\hline \multirow[t]{2}{*}{ Parameter (unit) } & \multicolumn{3}{|l|}{ Summer } & \multicolumn{3}{|l|}{ Winter } \\
\hline & inlet & outlet & removal & inlet & outlet & removal \\
\hline $\mathrm{COD}\left(\mathrm{mgO}_{2} / \mathrm{L}\right)$ & $564 \pm 29$ & $89 \pm 3$ & 84.2 & $1003 \pm 48$ & $435 \pm 13$ & 56.6 \\
\hline $\mathrm{TOC}(\mathrm{mgC} / \mathrm{L})$ & $201 \pm 2$ & $57 \pm 1$ & 71.6 & $340 \pm 3$ & $214 \pm 2$ & 37.1 \\
\hline $\mathrm{NH}_{4}(\mathrm{mgN} / \mathrm{L})$ & $1.2 \pm 0.2$ & $65 \pm 0.2$ & & $0.3 \pm 0.2$ & $9 \pm 0.2$ & \\
\hline $\mathrm{NO}_{3}(\mathrm{mgN} / \mathrm{L})$ & $445 \pm 5$ & $345 \pm 5$ & & $612 \pm 5$ & $598 \pm 5$ & \\
\hline $\mathrm{N}_{\text {tot }}(\mathrm{mgN} / \mathrm{L})$ & $446.2 \pm 5.2$ & $410 \pm 5.2$ & 8.1 & $612.3 \pm 5.2$ & $607 \pm 5.2$ & 0.9 \\
\hline $\mathrm{P}_{\text {tot }}(\mathrm{mgP} / \mathrm{L})$ & $2.1 \pm 0.1$ & $1.9 \pm 0.1$ & 9.6 & $1.1 \pm 0.1$ & $0.9 \pm 0.1$ & 18.1 \\
\hline $\mathrm{TA}\left(\mathrm{mgCaCO}_{3} / \mathrm{L}\right)$ & $465 \pm 24$ & $367 \pm 24$ & 21.1 & $752 \pm 24$ & $548 \pm 24$ & 27.1 \\
\hline Toxicity-Daphnia (Uta) & 1.2 & 7.7 & - & - & - & - \\
\hline Color (TCU) & $845 \pm 10$ & $52 \pm 1$ & 93.8 & $1596 \pm 10$ & $81 \pm 1$ & 94.9 \\
\hline $\mathrm{EC}(\mathrm{ms} / \mathrm{cm})$ & 8.53 & 7.44 & & 8.36 & 7.48 & \\
\hline DEHP $(\mu \mathrm{g} / \mathrm{L})$ & $19.8 \pm 2.3$ & ND & 100 & $22.1 \pm 2.3$ & $6.5 \pm 2.3$ & 70.6 \\
\hline
\end{tabular}

Table 5

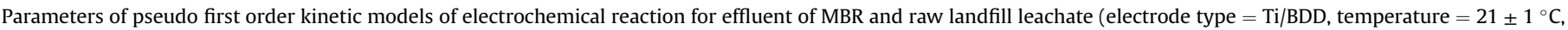
current intensity $=3 \mathrm{~A}$ ).

\begin{tabular}{|c|c|c|c|c|c|c|c|c|}
\hline \multirow{2}{*}{$\frac{\text { Status }}{\text { Parameter }}$} & \multicolumn{4}{|c|}{ Effluent of MBR } & \multicolumn{4}{|c|}{ Raw Landfill Leachate } \\
\hline & $\mathrm{K}(1 / \mathrm{h})$ & $\mathrm{K}_{\mathrm{m}} \times 10^{-6}(\mathrm{~m} / \mathrm{s})$ & $\mathrm{t}_{1 / 2}(\mathrm{~min})$ & $\mathrm{R}^{2}(\%)$ & $\mathrm{K}(1 / \mathrm{h})$ & $\mathrm{K}_{\mathrm{m}} \times 10^{-6}(\mathrm{~m} / \mathrm{s})$ & $\mathrm{t}_{1 / 2}(\mathrm{~min})$ & $\mathrm{R}^{2}(\%)$ \\
\hline COD & 0.86 & 37 & 48.4 & 98.3 & 0.45 & 19 & 92.1 & 99 \\
\hline TOC & 0.31 & 13 & 133 & 91.7 & 0.16 & 6.8 & 259.1 & 81.1 \\
\hline Color & 1.11 & 47 & 37.4 & 79.5 & 0.56 & 24 & 73.8 & 96.8 \\
\hline
\end{tabular}

was transformed into the smaller molecule (color removal), followed by oxidation of medium size DOM (TOC removal). The presence of high concentration of humic substances in raw LFL hampered the mineralization of DOM over the first $2 \mathrm{~h}$ of the treatment. When color was sufficiently removed, mineralization of DOM started (high TOC removal) (revolution of COD, color and TOC are presented in supplementary files: Fig. 6-S). COD removal rate for both raw and treated LFL followed the first-order kinetics. The constant rate of EOP also depended on the initial concentration of contaminants. For raw LFL, the half-life of COD, TOC and color was exactly the half of effluent of MBR.

For the additional experiments, the volume of $20 \mathrm{~L}$ of LFL was pretreated using EOP pilot. Unlike the previous experiment, color removal efficiency was selected for the process optimization, as it indicated the presence of non-biodegradable humic substance.
Therefore, removal of $95 \%$ of the color was selected as the optimum treatment time of EOP, which occurred at $41 \mathrm{~h}$. The performance of EOP for all parameters is shown in Table 6. Ammonia removal from raw LFL using EOP was very low, around $12 \%$. This value was consistent with that reported ( $8 \%$ of ammonia removal) by Urtiaga et al. (2009), because it requires indirect oxidation. Over the first hours of EOP, direct anodic oxidation on the surface of electrode was more dominant than indirect oxidation by means of hypochlorous acid $(\mathrm{HClO})$ generated during electrolysis (Anglada et al., 2011; Urtiaga et al., 2009; Zhou et al., 2016). In fact, in the presence of chloride ions in solution, these ions can be oxidized into chlorine $\left(\mathrm{Cl}_{2}\right)$, followed by the hydrolysis of $\mathrm{Cl}_{2}$ into hypochlorous acid $(\mathrm{HClO})$. With the exception of COD, the other parameters (such as TOC and DEHP) were faintly removed by EOP owing to its complexity. 
Table 6

Performance of EOP for raw landfill leachate (electrode type $=$ Ti/BDD temperature $=20 \pm 1{ }^{\circ} \mathrm{C}, \mathrm{pH}=8.1 \pm 0.2$, current intensity $=3 \mathrm{~A}$, voltage $=9.8 \mathrm{~V}$, reaction time $=41 \mathrm{~h}$ ).

\begin{tabular}{llll}
\hline Parameter (unit) & Inlet & Outlet & Removal (\%) \\
\hline $\mathrm{COD}\left(\mathrm{mgO}_{2} / \mathrm{L}\right)$ & $1485 \pm 83$ & $639 \pm 24$ & $57.0 \pm 1.1$ \\
$\mathrm{TOC}(\mathrm{mgC} / \mathrm{L})$ & $385 \pm 22$ & $248 \pm 12$ & $35.8 \pm 0.6$ \\
$\mathrm{NH}_{4}(\mathrm{mgN} / \mathrm{L})$ & $710 \pm 9$ & $623 \pm 82$ & $12.3 \pm 10.3$ \\
$\mathrm{NO}_{3}(\mathrm{mgN} / \mathrm{L})$ & $1.2 \pm 0.7$ & $65 \pm 81$ & - \\
$\mathrm{N}_{\text {tot }}(\mathrm{mgN} / \mathrm{L})$ & $712 \pm 10$ & $688 \pm 23$ & $3.4 \pm 1.8$ \\
$\mathrm{PO}_{4}(\mathrm{mgP} / \mathrm{L})$ & $4.3 \pm 1.2$ & $3.6 \pm 0.9$ & $16.3 \pm 1.9$ \\
$\mathrm{P}_{\text {tot }}(\mathrm{mgP} / \mathrm{L})$ & $5.7 \pm 1.1$ & $4.1 \pm 0.9$ & $28.1 \pm 1.6$ \\
$\mathrm{TA}(\mathrm{mgCaCO} / \mathrm{L})$ & $5555 \pm 1210$ & $4170 \pm 478$ & $24.9 \pm 6.4$ \\
Toxicity-Daphnia (Uta) & 15 & 17 & - \\
Toxicity-Vibrio fischeri (Uta) & 53 & 27 & 49 \\
Color $(\mathrm{TCU})$ & $1904 \pm 22$ & $52 \pm 101$ & $97.3 \pm 5.2$ \\
DEHP $(\mu \mathrm{g} / \mathrm{L})$ & $61 \pm 11$ & $50.8 \pm 9$ & $16.7 \pm 11.1$ \\
\hline
\end{tabular}

Table 7

Operating condition during optimization period of MBR for treatment of pretreated landfill leachate.

\begin{tabular}{lll}
\hline Parameter (unit) & \multicolumn{2}{l}{ Stage } \\
\cline { 2 - 3 } & 1 & 2 \\
\hline Operation period (day) & 20 & 14 \\
HRT (h) & 46 & 24 \\
SRT (day) & 100 & 56 \\
TS (g/L) & $14.161 \pm 1.176$ & $16.864 \pm 0.438$ \\
VS (g/L) & $6.694 \pm 0.422$ & $9.019 \pm 0.323$ \\
Turbidity (NTU) & $55 \pm 12$ & $67 \pm \pm 14$ \\
OLR (COD/L/day) & $0.475 \pm 0.107$ & $1.2 \pm 0.207$ \\
F/M ratio (kg COD/kg VS/day) & $0.069 \pm 0.015$ & $0.132 \pm 0.024$ \\
\hline
\end{tabular}

Finally, the mineralization of portion of volatile fatty acid, partially removed phosphorous.

For optimization of MBR for pretreated landfill leachate low and high organic loading rate was tested ( 0.475 and $1.20 \mathrm{gCOD} / \mathrm{L} /$ day). The operating conditions and performances of MBR are illustrated in Tables 7 and 8. Since the toxicity of raw LFL was increased after electro-oxidation, nitrification was significantly affected (Table 8) because of hypochlorous acid and organochlorine compounds in the effluent. However, TOC removal was considerably increased in MBR when the effluent was pre-treated by EOP, as complex DOM was oxidized into low weight, biodegradable organic matter. DEHP, also, followed significant removal improvement (around 80\% removal), due to the oxidation of its complex HS carrier. Finally, elimination of residual emerging contaminants and ammonia decreased the toxicity of effluent.

\section{Discussion}

According to the characterization of raw landfill leachate (Table 2) with high concentration of ammonia and low BOD/COD ratio, it categorized as an old landfill leachate which was highly non-biodegradable (Aloui et al., 2009). In summer, the ratio of BOD/ COD was increased, while the wastewater was diluted; hence, the performance of MBR for COD, TOC and color removal was increased due to adsorption of recalcitrant humic acid on sludge. As LFL became more concentrated, BOD removal efficiency also decreased, because of increase in toxicity of influent. Nitrification on the other hand, was not affected by ammonia load rate, as nitrobacter and nitrosomonas bacteria are autotroph (Ahmed and Lan, 2012).

In EOP, the mass transport of pollutant $\left(\mathrm{K}_{\mathrm{m}}\right)$ value was calculated for COD of raw LFL around $1.9 \times 10^{-5} \mathrm{~m} / \mathrm{s}$ (Table 6) which was close to the $1.75 \times 10^{-5} \mathrm{~m} / \mathrm{s}$ reported by Anglada et al. (2011) and $3 \times 10^{-5} \mathrm{~m} / \mathrm{s}$ by Panizza and Martinez-Huitle (2013) for the BDD electrode. Further increase in current intensity could result in secondary reaction, such as oxygen evolution (supplementary files: appendix A). Furthermore, high concentration of alkalinity diminished the performance of EOP, since ions, such as $\mathrm{CO}_{3}^{2-}$ and $\mathrm{HCO}_{3}^{-}$ could act as a radical scavenger (Table 4 also showed the removal of TA) (Zhou et al., 2016).

Initial concentration of pollutant which reflected in seasonal changes was another important factor. An increase in the initial concentration of pollutant negatively decreased the constant firstorder kinetic; yet, it increased the removal of COD absolute value (Fernandes et al., 2012). By closely looking at Fig. 3, it could be understood that cost effectiveness of the EOP was increased for the initial concentration COD higher than $1000 \mathrm{mg} / \mathrm{L}$ (Anglada et al., 2010). In optimum condition, 84 and $94 \%$ of color and COD was removed by EOP for the treated LFL, which was comparable to the results of other studies (Bashir et al., 2013). For the raw LFL in optimal conditions, 57 and $36 \%$ of COD and TOC removal efficiencies have been reported (Table 6). The energy consumption required for the oxidation of treated and raw landfill leachate were estimated to be 167 and $70 \mathrm{KWh} / \mathrm{kg}$ COD, respectively. In a pilot EOP plant, this amount was around $120 \mathrm{KWh} / \mathrm{kg}$ COD, which was close to our result (Urtiaga et al., 2009). In another study, the addition of chlorine in LFL, decreased the amount of electricity utilization from an average 193 to $121 \mathrm{KWh} / \mathrm{kg}$ COD (Bashir et al., 2013). Panizza and Martinez-Huitle (2013) estimated around $50 \mathrm{KWh} / \mathrm{m}^{3}$ of energy consumption for $85 \%$ of COD removal using BDD electrode and current intensity of $2 \mathrm{~A}$.

By using the combination of MBR and EOP as the tertiary treatment, in the optimum operating condition for both processes, COD, TOC, ammonium and DEHP concentration was decrease into

Table 8

Performance of MBR for treatment of pretreated landfill leachate.

\begin{tabular}{|c|c|c|c|c|c|c|}
\hline \multirow[t]{3}{*}{ Parameter (unit) } & \multicolumn{6}{|l|}{ Stage } \\
\hline & \multicolumn{3}{|l|}{1} & \multicolumn{3}{|l|}{2} \\
\hline & Inlet & Outlet & Removal (\%) & Inlet & Outlet & Removal (\%) \\
\hline $\mathrm{COD}\left(\mathrm{mgO}_{2} / \mathrm{L}\right)$ & $915 \pm 138$ & $444 \pm 52$ & $50.4 \pm 12.8$ & $1226 \pm 276$ & $532 \pm 79$ & $56.1 \pm 5.6$ \\
\hline $\mathrm{TOC}(\mathrm{mgC} / \mathrm{L})$ & $232 \pm 33$ & $120 \pm 19$ & $48.3 \pm 4.5$ & $254 \pm 32$ & $142 \pm 21$ & $44.1 \pm 3.4$ \\
\hline $\mathrm{NH}_{4}(\mathrm{mgN} / \mathrm{L})$ & $619 \pm 75$ & $128 \pm 40$ & $79.3 \pm 2.3$ & $592 \pm 15$ & $361 \pm 50$ & $55.5 \pm 9.5$ \\
\hline $\mathrm{NO}_{3}(\mathrm{mgN} / \mathrm{L})$ & $1.2 \pm 0.5$ & $131 \pm 24$ & & $1.5 \pm 0.8$ & $117 \pm 65$ & \\
\hline $\mathrm{N}_{\text {tot }}(\mathrm{mgN} / \mathrm{L})$ & $620 \pm 76$ & $445 \pm 51$ & $28.2 \pm 3.1$ & $593 \pm 16$ & $471 \pm 81$ & $21.1 \pm 7.3$ \\
\hline $\mathrm{PO}_{4}(\mathrm{mgP} / \mathrm{L})$ & $3.1 \pm 2.1$ & $0.7 \pm 1.1$ & $77.4 \pm 12.8$ & $4.2 \pm 0.3$ & $0.6 \pm 0.9$ & $85.7 \pm 19.0$ \\
\hline $\mathrm{P}_{\text {tot }}(\mathrm{mgP} / \mathrm{L})$ & $3.7 \pm 2.2$ & $0.7 \pm 1.1$ & $81.1 \pm 11.2$ & $4.5 \pm 0.5$ & $0.6 \pm 0.9$ & $86.7 \pm 16.7$ \\
\hline $\mathrm{TA}\left(\mathrm{mgCaCO}_{3} / \mathrm{L}\right)$ & $3939 \pm 933$ & $2850 \pm 1143$ & $27.6 \pm 10.0$ & $4410 \pm 775$ & $3310 \pm 355$ & $24.9 \pm 6.7$ \\
\hline Toxicity-Daphnia (Uta) & 7.7 & 2.7 & 64.9 & - & - & - \\
\hline Toxicity-Vibrio fischeri (Uta) & 27 & 1.5 & 94.4 & - & - & - \\
\hline Color (TCU) & $55 \pm 12$ & $15 \pm 11$ & $72.7 \pm 11.5$ & $94 \pm 32$ & $22 \pm 12$ & $76.6 \pm 6.7$ \\
\hline DEHP $(\mu \mathrm{g} / \mathrm{L})$ & $49 \pm 4$ & $9.8 \pm 4.1$ & $80 \pm 15.5$ & $55 \pm 3$ & $14.6 \pm 5.8$ & $73.5 \pm 21.1$ \\
\hline
\end{tabular}




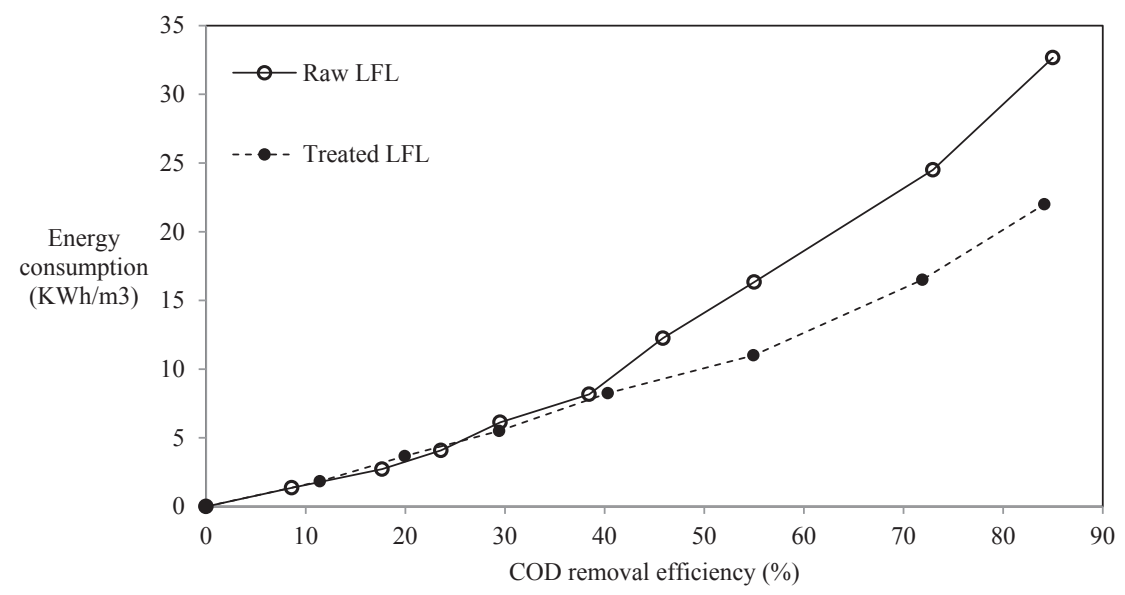

(a)

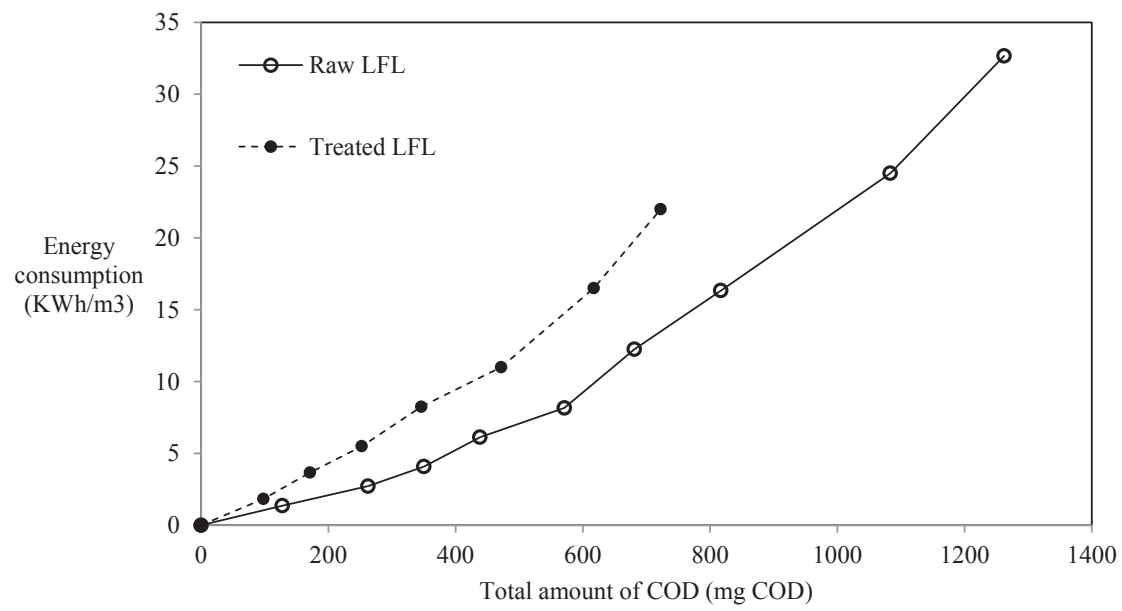

(b)

Fig. 3. Energy consumption of electro-oxidation process according to (a) COD removal efficiency (b) total amount of COD in optimum operating condition.

$89,57,65$ and $9 \mathrm{mg} / \mathrm{L}$, respectively. Furthermore, organochlorinated compounds were produced by reaction of chlorine radical with high concentration of dissolved organic matter and ammonia (Anglada et al., 2011; Bashir et al., 2013), which increased the toxicity. Chloramine, chloroform, dichloroethane and dichloroacetonitrile with the total concentration of $104-2100 \mu \mathrm{g} / \mathrm{L}$, are the main organochlorinated compounds which are volatile in nature (Anglada et al., 2011; Bashir et al., 2013).

Using EOP as the pretreatment considerably decreased the energy consumption for both EOP and MBR. Moreover, final effluent toxicity was not increased more than 1.5 Uta for Daphnia, which was lower than 2.7 for the effluent of post-treated LFL by EOP. However, residual chlorine and nitrite radicals are the main reason of inhibition in nitrification in MBR for treatment.

By considering factors, such as performance of processes, energy consumption, toxicity of final effluent, and removal of emerging contaminants, it seems that utilization of EOP as a post treatment method was more viable.

\section{Conclusion}

Old landfill leachate is considered as one of the most problematic wastewater to treat, because of high concentration of nonbiodegradable organic matter, largely humic substances, ammonia, heavy metal and DEHP. As toxic landfill leachate contains low amount of BOD and phosphorous, efficient treatment of HS and emerging contaminants by even highly sophisticated MBR process has been challenging. Electro-oxidation process was used to properly handle the residual COD and DEHP without production of extra sludge. However, the effluent of EOP was more toxic due to the presence of organochlorine compounds, remaining radical and ammonia.

Application of EOP before MBR was considered a substitutional option because of following reasons:

(1) Oxidation of high molecular weight organic compounds into smaller molecules enhanced MBR performance in the term of TOC removal efficiency from 23 to $48 \%$ for the raw and pretreated LFL, respectively.

(2) DEHP mainly adsorbed to humic substances; thus, oxidation of humic substances increased its bioavailability, leading to enhancement its removal efficiency from 66 to $80 \%$ for electro-oxidized landfill leachate.

(3) Residual radicals and organochlorinated compounds produced in EOP, was sufficiently removed in aeration basin of MBR by air stripping and adsorption on sludge.

(4) Electro-oxidation of raw landfill leachate required considerably less amount of electricity $\left(16 \mathrm{KWh} / \mathrm{m}^{3}\right.$ and $70 \mathrm{KWh} / \mathrm{kg}$ 
COD), in comparison to bio-treated LFL ( $22 \mathrm{KWh} / \mathrm{m}^{3}$ and $167 \mathrm{KWh} / \mathrm{kg}$ COD).

The only problem associated with the combination of EOP before MBR was noxious effect of residual radical on nitrification, which increased the effluent concentration of ammonia. Utilization of radical scavenger after electro-oxidation or keeping electrooxidized LFL in storage tank before introduction into aeration basin could be the solution to this challenge. Using reverse osmosis is another way to properly remove the remaining organic matter, metal, nitrate and phosphate from bio-treated landfill leachate.

\section{Acknowledgement}

Sincere thanks are accrued to the National Sciences and Engineering Research Council of Canada (NSERC Grant Number: I2IPJ 461378) for their financial contribution to this study.

\section{Appendix A. Supplementary data}

Supplementary data related to this article can be found at http:// dx.doi.org/10.1016/j.jenvman.2016.10.010.

\section{References}

Ahmed, F.N., Lan, C.Q., 2012. Treatment of landfill leachate using membrane bioreactors: a review. Desalination 287, 41-54.

Akkanen, J., Penttinen, S., Haitzer, M., Kukkonen, J.V.K., 2001. Bioavailability of atrazine, pyrene and benzo[a]pyrene in European river waters. Chemosphere 45, 453-462.

Aloui, F., Fki, F., Loukil, S., Sayadi, S., 2009. Application of combined membrane biological reactor and electro-oxidation processes for the treatment of landfill leachates. Water Sci. Technol. 60, 605.

Anglada, A., Ortiz, D., Urtiaga, A.M., Ortiz, I., 2010. Electrochemical oxidation of landfill leachates at pilot scale: evaluation of energy needs. Water Sci. Technol. 61, 2211-2217.

Anglada, A., Urtiaga, A., Ortiz, I., Mantzavinos, D., Diamadopoulos, E., 2011. Borondoped diamond anodic treatment of landfill leachate: evaluation of operating variables and formation of oxidation by-products. Water Res. 45, 828-838.
Bashir, M.J., Isa, M.H., Kutty, S.R., Awang, Z.B., Aziz, H.A., Mohajeri, S., Farooqi, I.H., 2009. Landfill leachate treatment by electrochemical oxidation. Waste Manag. 29, 2534-2541.

Bashir, M.J.K., Aziz, H.A., Aziz, S.Q., Abu Amr, S.S., 2013. An overview of electrooxidation processes performance in stabilized landfill leachate treatment. Desalination Water Treat. 51, 2170-2184.

Chu, Y.-Y., Zhu, M.-H., Liu, C., 2015. Electrochemical treatment of biotreated landfill leachate using a porous carbon nanotube-containing cathode: performance, toxicity reduction, and biodegradability enhancement. Environ. Eng. Sci. 32, 445-450.

Deng, Y., Englehardt, J.D., 2007. Electrochemical oxidation for landfill leachate treatment. Waste Manag. 27, 380-388.

Fernandes, A. Afonso, N., Coelho, J. Pacheco, M., Ciriaco, L. Lopes, A., 2015 Chemical and electrochemical combined processes to treat sanitary landfill leachates. Port. Electrochimic. Acta 33, 241-248.

Fernandes, A., Pacheco, M.J., Ciriaco, L., Lopes, A., 2012. Anodic oxidation of a biologically treated leachate on a boron-doped diamond anode. J. Hazard. Mater. 199-200, 82-87.

Gotvajn, A.Z., Tisler, T., Zagorc-Koncan, J., 2009. Comparison of different treatment strategies for industrial landfill leachate. J. Hazard. Mater. 162, 1446-1456.

Kjeldsen, P., Barlaz, M.A., Rooker, A.P., Baun, A., Ledin, A., Christensen, T.H., 2002. Present and long-term composition of MSW landfill leachate: a review. Crit. Rev, Env, Sci. Tecnol. 32, 297-336.

Oturan, N., Van Hullebusch, E.D., Zhang, H., Mazeas, L., Budzinski, H., Le Menach, K., Oturan, M.A., 2015. Occurrence and removal of organic micropollutants in landfill leachates treated by electrochemical advanced oxidation processes. Environ. Sci. Technol. 49, 12187-12196.

Panizza, M., Martinez-Huitle, C.A., 2013. Role of electrode materials for the anodic oxidation of a real landfill leachate-comparison between Ti-Ru-Sn ternary oxide, $\mathrm{PbO}_{2}$ and boron-doped diamond anode. Chemosphere 90, 1455-1460.

Schwarzenbeck, N., Leonhard, K., Wilderer, P., 2004. Treatment of landfill leachateHigh tech or low tech? A case study. Water Sci. Technol. 48, 277-284.

Urtiaga, A., Rueda, A., Anglada, A., Ortiz, I., 2009. Integrated treatment of landfill leachates including electrooxidation at pilot plant scale. J. Hazard Mater. 166, 1530-1534.

Zhou, B., Yu, Z., Wei, Q., Long, H., Xie, Y., Wang, Y., 2016. Electrochemical oxidation of biological pretreated and membrane separated landfill leachate concentrates on boron doped diamond anode. Appl. Surf. Sci. 377, 406-415.

Zolfaghari, M., Drogui, P., Seyhi, B., Brar, S.K., Buelna, G., Dubé, R., Klai, N., 2015. Investigation on removal pathways of Di 2-ethyl hexyl phthalate from synthetic municipal wastewater using a submerged membrane bioreactor. J. Environ. Sci. $37,37-50$.

Zolfaghari, M., Drogui, P., Seyhi, B., Brar, S.K., Buelna, G., Dubé, R., 2016. Effect of bioavailability on the fate of hydrophobic organic compounds and metal in treatment of young landfill leachate by membrane bioreactor. Chemosphere $161,390-399$. 